\title{
Process Optimization for Flavoured Milk Added with Piper betel leaves
}

\author{
Vaibhav S. Kamble, Dnyaneshwar D. Patange*, Dinakar K. Kamble, \\ Karishma S. Kamble and Sharad J. Patil
}

\begin{abstract}
Faculty member of Division of Animal Husbandry and Dairy Science, College of Agriculture, Kolhapur-416004, India

*Corresponding author
\end{abstract}

\begin{tabular}{|l|}
\hline Ke y w o r d s \\
$\begin{array}{l}\text { Flavoured milk, } \\
\text { Piper betel leaves, } \\
\text { RSM, Storage study }\end{array}$ \\
\hline Article Info \\
\hline $\begin{array}{l}\text { Accepted: } \\
\text { 07 December } 2018 \\
\text { Available Online: } \\
\text { 10 January } 2019\end{array}$ \\
\hline
\end{tabular}

\section{A B S T R A C T}

Considering the increasing demand to flavored milk and nutritional, therapeutic and post meal mouth freshener property of Piper betel leaves the present study was undertaken with object to optimize the levels of Piper betel leaves for developing flavoured milk and to study the sensory qualities as well as physico-chemical properties of Piper betel flavoured milk. Initially fresh cow milk was standardized to $2 \%$ fat and aqueous extract of piper betel leaves (PBLE) of different verities were prepared. The level of PBLE and sugar were optimized using CCRD of RSM. It was found that the flavoured milk prepared by the addition of the PBLE of Calcutta variety had obtained maximum scored for all the sensory qualities among other two varieties under study. In RSM trial the results showed that the colour and appearance, sweetness and overall acceptability score of milk was recorded maximum for formulation, having 5 per cent PBLE and 10 per cent sugar. The best solution exerted through the software, contained PBLE and sugar at 5.15 and 10.30 per cent, respectively. The validation of the prediction was done by actual observations recorded for sensory score. The optimized formulation had 8.49, 8.50, 7.40, 8.30 and 8.15 score for colour and appearance, flavour, consistency, sweetness and overall acceptability, respectively. Consumers as a whole liked the product 'moderately' to 'very much' with an average score of 7.70 .

\section{Introduction}

It is estimated that about 46 per cent of milk is used as market milk while 54 per cent of total milk is converted into various milk products. Market milk means that milk, which is sold into the market and directly consumed by the individual (David, 2006). Market milk includes cow milk, buffalo milk, standardized milk, toned milk, double toned milk, skim milk, sterilized milk, full cream milk and flavored milk of which flavoured milk caters to the desire of the consumers for variety and a different experience in flavour. Some consumers do not like the flavour of natural milk but appreciate the nutritional value of milk in the form of flavour milk (Bisig, 2011). As per FSSR, (2011) flavoured milk, by whatever name called, may contain nuts (whole, fragmented or ground) chocolate, coffee or any other edible flavour, food colours and cane sugar. Flavoured milk shall 
be pasteurized, sterilized or boiled. The type of milk shall be mentioned on the label. Bisig (2011) defined flavoured milk as are ready to drink products made from unfermented milk of different fat contents mixed with ingredients like sugar or other sweetener, cocoa powder, fruit juice, coffee, aroma agents, and /or other ingredients and additives. Flavoured milk can also encourage children to consume more milk, and some milk is used in school milk programmes.

Flavoured milks provide another option for meeting the recommended intakes of dairy products. The most popular flavour used in the flavoured milk are chocolate, coffee, vanilla, strawberry, rose, pineapple, mango, almond, banana etc., these flavoring materials are mostly synthetic or animal origin. Addition of synthetic flavour and color in food products may results in hyperactivity and behavioral problems in children and due to their toxic nature, manufactures are driving towards the natural color.

More and more people are interesting in herbal or natural way of life and for that they have used natural flavoring and colour material in preparation of foods (Palthur et al., 2014).Here is the official FDA definition of natural flavoring: "Natural flavor is the essential oil, oleoresin, essence or extractive, protein hydrolysate, distillate, or any product of roasting, heating or enzymolysis, which contains the flavoring constituents derived from a spice, fruit or fruit juice, vegetable or vegetable juice, edible yeast, herb, bark, bud, root, leaf or similar plant material, Several natural flavors and colors are available in the market such as caramel, carotenoids, carmine and Anthocyanin.

The deep green heart shaped Piper betel leaves are popularly known as Paan in India. It is also known as Nagaballi, Nagurvel, Saptaseera, Sompatra, Tamalapaku, Tambul,
Tambuli, Vakshapatra, Vettilai, Voojangalata etc. in different parts of India. Piper betel leaves is an aromatic leaves belonging to Piperaceae family commonly used as masticatory as it is rich nutritionally and is known medicinally as a stimulant and carminative, an antiseptic and an expectorant.

It is composed of essential oils (0.7-2.6 per cent), and other constituents viz., carbohydrate (0.5-6.1 per cent), fat (0.4 -1.0 per cent) protein (3.0 -3.5 per cent), fiber (2.3 per cent), minerals (2.3-3.3 per cent), water (80-90 per cent) with good source of water and oil soluble vitamins (Guha, 2006 and Ramamurthi and Usha, 2012). The leaves also contain the enzyme like diastase and catalase besides a significant amount of all the essential amino acids except lysine, hystidine and arginine.

The leaves contain aromatic volatile oil composed by a phenol called chavicol which has powerful antiseptic properties. The alkaloid arakene is stimulant of muscular and mental efficiency. It is also used as mouth freshener after meal (Kumar, 1999).

Considering the increasing demand to flavored milk and flavoring, nutritional, therapeutic and post meal mouth freshener property of Piper betel leaves, the present investigation was carried out.

\section{Materials and Methods}

\section{Materials}

Fresh milk of crossbreed cow was procured from Dairy Farm, College of Agriculture, Kolhapur. Whereas, Piper Betel leave of Calcutta, Banaras and Maghai variety and crystalline cane sugar were procured from local market of Kolhapur city. Carboxymethyl cellulose (E466) of Bijur Scooper Foods Pvt. Ltd. make was used as stabilizing agent. 


\section{Methodology}

\section{Preparation of Piper betel leaves extract}

For the preparation of extract, fresh piper betel leaves were washed under running tap water, of which $10 \mathrm{~g}$ leaves were crushed with $100 \mathrm{ml}$ distilled water in a grinder for 2-3 min. The leaves juice was filtered through two folded muslin cloth and were used in the preparation of flavoured milk.

\section{Preparation of flavoured milk}

Flavoured milk was prepared as per the method suggested by Palthur et al., (2014) for the preparation of ginger flavoured milk with slight modification (Fig. 1). Milk was preheated to $40^{\circ} \mathrm{C}$ and filtered through a muslin cloth followed by standardiation to $2 \%$ fat level, furthur it wasalllowed to heat at $65^{\circ} \mathrm{C}$. At this time sugar and PBLE were added as per the treatment combination (Table 1)where as CMC stabilizer was used @ $0.1 \%$ of milk.

The contents were mixedproperly and heated for another 2 min fallowed by homogenizaton at 2000 psi. At last milk was fill in $200 \mathrm{ml}$ transparent glass bottle which was then sealed by crown cap and placed in hot water bath maintained at $65^{\circ} \mathrm{C}$ for 45 min, subsequently when bottles get cooled it was transfered in refrigerator at $5^{\circ} \mathrm{C}$.

\section{Process optimization}

\section{Selection of Piper betel variety}

Piper betel leaves of Calcutta, Banaras and Maghai variety, were washed under running tap water. The extract from leaves were obtained as procedure given above. Flavoured milk was prepared by addition of extract of thse varieties @ 5\% of milk with addition of $10 \%$ sugar and $0.1 \% \mathrm{CMC}$ in all samples. The treatment included control i.e. milk without PBLE $\left(\mathrm{LF}_{0}\right)$, flavoured milk with
PBLE of Calcutta variety $\left(\mathrm{LF}_{1}\right)$, flavoured milk with PBLE of Maghai variety $\left(\mathrm{LF}_{2}\right)$ and flavoured milk with PBLE of Banaras variety $\left(\mathrm{LF}_{3}\right)$.Samples were evaluated for sensory qualities and one best was selected.

\section{Selection of level of PBLE for preparation of flavoured milk}

In priliminary experiment the leaf extract Calcutta varities of piper betel was mixed @ $0,1,3,5,7$ and $11 \%$ of milk (v/v),sweented with $10 \%$ sugar and evaluated for sensory qualities. Theflavoured milk added with PBLE @ 3,5 and 7\% exerted score above 7 (like moderately) on 9-point hedonic scale. These levels of PBLE were considered for RSM experiment.

\section{Optimization of level of piper betel leaves extract (PBLE) and sugar}

Central Composite Rotatable Design (CCRD) of Response Surface Methodology (RSM) used to optimize the level of PBLE and sugar for two factors as independent variables (www.statease.com).The level of ingredients of the design matrix for the experiment is presented in Table1.

The data generated was analyzed using Design-Expert Software and a generalized polynomial equation was obtained for each response. Adequacy of model was evaluated using $\mathrm{F}$ ratio and co-efficient of determination $\left(\mathrm{R}^{2}\right)$. The lack of fit was calculated. Model was considered adequate when F-calculated was more than Table F-value and $\mathrm{R}^{2}$ will be more than 70 per cent (Henika, 1972). The effect of the variables at linear, quadratic and interactive levels on individual responses was described using 1 and 5 per cent levels of confidence. From the results obtained through sensory evaluation of flavored milk with different levels of PBLE and sugar, most desirable combination was selected by verification of their sensory qualities. 


\section{Analytical work}

\section{Physico-chemical analysis}

The product was analysed for fat, protein, lactose, sucrose, TS content by AOAC (2000) method, whereas, specific gravity and viscosity were determined as per protocol given by Mann et al., (2012) and Anandh et al., (2014). pH was known estimated by using Oroion 3 star $\mathrm{pH}$ benchtop $\mathrm{pH}$ meter according to the mentioned standard procedure.

\section{Sensory evaluation}

Sensory evaluation of PBLE added flavoured milk samples were carried out by a semitrained panel of judges from the staff of the Division of Animal Husbandry and Dairy Science College of Agriculture, Kolhapur, by using 9- point Hedonic scale (Appendix -I) as described by (Hue, 1993).

For colour and appearance, flavour, consistency, sweetness and overall acceptability. Samples were served in coded number flask. Water was given between two samples to cleanse the mouth.

\section{Consumer acceptability study}

The experimental flavoured milk was subjected to consumer acceptance. The test was carried out with 200 respondents from local area. The responses were collected on pre designed questionnaire.

\section{Statistical analysis}

Data generated during selection of variety of PBLE were analyzed by employing CRD technique (Snedecor and Cochran, 1967). Whereas the level of PBLE and sugar was optimized using Stat-Ease Design Expert 7.0.0 package procured from stat ease Inc., USA (www.statease.com).

\section{Results and Discussion}

Selection of varieties of PBLE in the preparation of flavored milk

The flavoured milk prepared from extract of Calcutta variety had significant $(\mathrm{p}<0.05)$ highest score for colour and appearance (score $=8.40 \pm 0.02$ ), flavour ( score $=8.38 \pm 0.05$ ) and overall acceptability (score $=7.36 \pm 0.02$ ) over the rest of the two verities under study (Table $2)$.

The variation in color and appearance score might be because of the natural variation in colour of Piper betel leaves of different verities. Rai et al., (2011) studied that Piper betel contain a wide variety of biological active compound whose concentration depends on the variety of plants, season and climate. The effect of PBLE of different varieties of leaves was merely affected on sweetness score of flavoured milk due to presence of sugar at equal level in the flavoured milk.

\section{Optimization of level of PBLE and sugar through RSM}

Effect of level of PBLE and sugar on sensory qualities of flavored milk

The colour and appearance score of Piper betel flavoured milk ranged from 7.5 to 8.6. The maximum score was obtained for formulation, which had 5 per cent PBLE and 10 per cent sugar. PBLE shown significant $(\mathrm{P}<0.05)$ effect on colour and appearance score of flavoured milk at linear (positively) and quadratic (negatively) term. The regression analysis of a data presented in Table 3 reveals that the coefficient of determination $\left(R^{2}\right)$ for colour and appearance score was 0.9437 . The adequate precision was found to be 12.83 , appreciably higher than the minimum desirable (4) for high prediction 
ability. Further, the statistical analysis indicated that the model fitted the data well (model ' $F$ ' value 23.48). It can be seen from fig. 2, that increasing sugar level slowly increase in the colour and appearance score whereas, it increased rapidly as the PBLE level increases up to a certain point, beyond that the colour and appearance was decreased. Similar observations were recorded by Natisti et al., (2014) during reported that colour and appearance score of flavoured soy ice cream with addition of lemongrass leaf extract.

Flavour score of Piper betel flavoured milk ranged from 7.5 to 8.5 . The regression analysis of data for flavour score reveals that the coefficient of determination $\left(\mathrm{R}^{2}\right)$ was 0.9568.It is cleared from fig 3 that flavour score increased with increasing level of PBLE and sugar level at certain point but beyond that flavour score declined slowly. In addition, the interaction effect of PBLE and sugar was exerted in same manner. Sudha et al., (2015) mentioned the decline in flavour score at higher concentration of sugar in the preparation flavour milk. Pugazhenthi and Jothylingam, (2010) recorded the maximum score for low calorie herbal flavoured milk, by incorporating Aloe-vera pulp extract at $5 \%$.

The response surface uncoded equation derived for predicting flavour score could be given as:

Flavour $=-16.99511+1.85876 *$ PBLE + $4.00970 *$ sugar $-0.056250 *$ PBLE * sugar $0.12629 *$ PBLE $^{2}-0.18017 * \operatorname{sugar}^{2}$

From table 4, it is clear that linear and quadratic interaction term sugar formed significantly changes in the consistency score indicating its importance in mouth feeling of products. Sugar in dairy products is not only responsible for sweetness; it also contributes to thickness. Oliveira et al., (2015) reported creaminess. The interaction effect of PBLE and sugar levels on consistency score had significant. The sweetness score of flavored milk was ranged from 7.50 to 8.50 . From the fig 4 , it is seen that as the sugar percentage increased the overall acceptability score increased, however it was largely affected due to PBLE level. From fig 5, it is clear that maximum overall acceptability score was recorded for the product containing 5 and 10 per cent PBLE and sugar, respectively. The minimum overall acceptability score was recorded for product containing 3 and 9 per cent PBLE and sugar respectively.

\section{Effect of level of PBLE and sugar on physico-chemical qualities of flavored milk}

It is observed from table 5 that the $\mathrm{pH}$, specific gravity, fat, sucrose and Total solids were decreased with increase in the level of PBLE and sugar. The adequate precision was found to be appreciably higher than the minimum desirable (4) for high prediction ability and the model ' $F$ ' value implies the model was significant for all physicochemical properties (Table 6).

The interaction effect of PBLE and sugar level on the $\mathrm{pH}$, specific gravity, Total solids was in positive terms and for viscosity, fat, lactose had significantly affected but negatively. The coefficient for viscosity of Piper betel flavored milk model shows that the level of different variables had significant effect. The viscosity of flavored milk was also affected (Fig.6) by the level of sugar at linear, quadratic and interactive terms.

The quadratic term sugar also showed the significant effect in negative terms. At linear term the sucrose content and total solids were significant. Poul et al., (2009) reported that with increase in the content of custard apple milk shake the total solid content of the milk shake was also increased. 
Table.1 Experimental level of Independent variables in RSM

\begin{tabular}{|l|c|c|}
\hline Std & PBLE $\left(\mathbf{X}_{\mathbf{1}}\right) \boldsymbol{\%}$ & Sugar $\left(\mathbf{X}_{\mathbf{2}}\right) \boldsymbol{\%}$ \\
\hline $\mathbf{1}$ & 5 & 11 \\
\hline $\mathbf{2}$ & 3 & 9 \\
\hline $\mathbf{3}$ & 3 & 11 \\
\hline $\mathbf{4}$ & 5 & 10 \\
\hline $\mathbf{5}$ & 5 & 10 \\
\hline $\mathbf{6}$ & 5 & 10 \\
\hline $\mathbf{7}$ & 3 & 10 \\
\hline $\mathbf{8}$ & 7 & 11 \\
\hline $\mathbf{9}$ & 5 & 9 \\
\hline $\mathbf{1 0}$ & 5 & 10 \\
\hline $\mathbf{1 1}$ & 7 & 9 \\
\hline $\mathbf{1 2}$ & 5 & 10 \\
\hline $\mathbf{1 3}$ & 7 & 10 \\
\hline
\end{tabular}

Table.2 Effect of varieties PBLE on sensory qualities (score*) of flavoured milk

\begin{tabular}{|l|l|l|l|l|l|}
\hline \multirow{2}{*}{ Treatments } & \multicolumn{5}{|c|}{ Scores for sensory attributes } \\
\cline { 2 - 6 } & $\begin{array}{c}\text { Colour and } \\
\text { appearance }\end{array}$ & \multicolumn{1}{|c|}{ Flavour } & Consistency & Sweetness & $\begin{array}{l}\text { Overall } \\
\text { acceptability }\end{array}$ \\
\hline $\mathrm{LF}_{0}$ & $6.42^{\mathrm{a}} \pm 0.04$ & $6.35^{\mathrm{a}} \pm 0.04$ & $7.34 \pm 0.04$ & $7.34 \pm 0.12$ & $6.86^{\mathrm{a}} \pm 0.02$ \\
\hline $\mathrm{LF}_{1}$ & $8.40^{\mathrm{d}} \pm 0.02$ & $8.38^{\mathrm{d}} \pm 0.05$ & $7.38 \pm 0.03$ & $7.47 \pm 0.09$ & $7.93^{\mathrm{d}} \pm 0.03$ \\
\hline $\mathrm{LF}_{2}$ & $7.57^{\mathrm{b}} \pm 0.05$ & $7.14^{\mathrm{b}} \pm 0.04$ & $7.37 \pm 0.03$ & $7.34 \pm 0.09$ & $7.36^{\mathrm{b}} \pm 0.02$ \\
\hline $\mathrm{LF}_{3}$ & $7.82^{\mathrm{c}} \pm 0.02$ & $7.74^{\mathrm{c}} \pm 0.04$ & $7.29 \pm 0.03$ & $7.47 \pm 0.13$ & $7.58^{\mathrm{c}} \pm 0.03$ \\
\hline $\mathrm{CD}(\mathrm{P}<0.05)$ & 0.11 & 0.13 & $\mathrm{NS}$ & $\mathrm{NS}$ & 0.09 \\
\hline
\end{tabular}

$*$ Means \pm SE of five replications within column fallowed by same letter are non significantly different at $\mathrm{p}<0.05 \mathrm{NS}=$ Non significant

Table.3 Effect of ingredient levels on sensory attributes (score *) of flavored milk

\begin{tabular}{|c|c|c|c|c|c|c|c|}
\hline \multicolumn{9}{|c|}{ Ingredients } & \multicolumn{5}{c|}{ Sensory Score } \\
\hline Run & $\begin{array}{c}\text { PBLE } \\
(\boldsymbol{\%})\end{array}$ & $\begin{array}{c}\text { Sugar } \\
(\boldsymbol{\%})\end{array}$ & $\begin{array}{c}\text { Colour \& } \\
\text { appearance }\end{array}$ & Flavor & Consistency & Sweetness & $\begin{array}{c}\text { Overall } \\
\text { acceptability }\end{array}$ \\
\hline 1 & 5 & 9 & 8.20 & 8.00 & 7.20 & 7.60 & 7.75 \\
\hline 2 & 5 & 10 & 8.60 & 8.40 & 7.40 & 8.50 & 8.23 \\
\hline 3 & 5 & 11 & 8.30 & 8.40 & 7.55 & 8.00 & 8.06 \\
\hline 4 & 7 & 9 & 8.00 & 7.80 & 7.20 & 7.70 & 7.68 \\
\hline 5 & 3 & 10 & 7.60 & 7.75 & 7.40 & 8.10 & 7.71 \\
\hline 6 & 5 & 10 & 8.30 & 8.50 & 7.45 & 8.20 & 8.11 \\
\hline 7 & 3 & 9 & 7.50 & 7.50 & 7.30 & 7.50 & 7.45 \\
\hline 8 & 5 & 10 & 8.40 & 8.40 & 7.47 & 8.35 & 8.16 \\
\hline 9 & 5 & 10 & 8.50 & 8.50 & 7.48 & 8.25 & 8.18 \\
\hline 10 & 5 & 10 & 8.40 & 8.30 & 7.45 & 8.40 & 8.14 \\
\hline 11 & 7 & 11 & 7.80 & 7.75 & 7.60 & 7.90 & 7.76 \\
\hline 12 & 3 & 11 & 7.80 & 7.90 & 7.50 & 8.00 & 7.80 \\
\hline 13 & 7 & 10 & 7.90 & 8.00 & 7.45 & 8.30 & 7.91 \\
\hline
\end{tabular}


Table.4 Coefficients of quadratic polynomial model for coded sensory score attributes

\begin{tabular}{|c|c|c|c|c|c|}
\hline \multicolumn{7}{|c|}{ Sensory Score } \\
\hline Factor & $\begin{array}{c}\text { Colour \& } \\
\text { appearance }\end{array}$ & Flavors & Consistency & Sweetness & $\begin{array}{c}\text { Overall } \\
\text { acceptability }\end{array}$ \\
\hline Intercept & 8.41 & 8.41 & 7.44 & 8.32 & 8.15 \\
\hline PBLE(A) & $0.13^{*}$ & 0.067 & $8.333 \mathrm{E}-003$ & 0.050 & $0.065^{*}$ \\
\hline Sugar (B) & 0.033 & $0.12^{*}$ & $0.16^{*}$ & $0.18^{*}$ & $0.12^{*}$ \\
\hline $\mathrm{AB}$ & -0.12 & $-0.11^{*}$ & $0.050^{*}$ & -0.075 & -0.067 \\
\hline $\mathrm{A}^{2}$ & $-0.59^{*}$ & $-0.51^{*}$ & $-8.621-004$ & -0.084 & $-0.30^{*}$ \\
\hline $\mathrm{B}^{2}$ & -0.086 & $-0.18^{*}$ & $-0.051^{*}$ & $-0.48^{*}$ & $-0.20^{*}$ \\
\hline $\mathrm{R}^{2}$ & 0.9437 & 0.9568 & 0.9593 & 0.9377 & 0.9652 \\
\hline F-value & $23.48^{*}$ & $31.02^{*}$ & $32.96^{*}$ & $21.08^{*}$ & $38.78^{*}$ \\
\hline Mean & 8.10 & 8.09 & 7.42 & 8.06 & 7.92 \\
\hline SD & 0.11 & 0.092 & 0.032 & 0.10 & 0.060 \\
\hline $\begin{array}{c}\text { Adequate } \\
\text { Precision }\end{array}$ & 12.83 & 15.76 & 19.13 & 12.52 & 18.51 \\
\hline
\end{tabular}

(*Significant at 5\%)

Table.5 Effect of ingredient levels on physico-chemical qualities of flavoured milk

\begin{tabular}{|c|c|c|c|c|c|c|c|c|c|c|c|c|}
\hline Std & Run & $\begin{array}{c}\text { PBLE } \\
(\%)\end{array}$ & $\begin{array}{c}\text { Sugar } \\
(\%)\end{array}$ & pH & $\begin{array}{l}\text { Acidity } \\
\text { (\%LA) }\end{array}$ & $\begin{array}{l}\text { Specific } \\
\text { gravity }\end{array}$ & $\begin{array}{c}\text { Viscosity } \\
\text { (cP) }\end{array}$ & $\begin{array}{l}\text { Fat } \\
(\%)\end{array}$ & $\begin{array}{c}\text { Protein } \\
(\%)\end{array}$ & $\begin{array}{c}\text { Lactose } \\
(\%)\end{array}$ & $\begin{array}{c}\text { Sucrose } \\
(\%)\end{array}$ & $\begin{array}{c}\text { Total } \\
\text { solid } \\
(\%)\end{array}$ \\
\hline 8 & 1 & 5 & 9 & 6.51 & 0.168 & 1.067 & 8.21 & 1.69 & 3.62 & 4.68 & 8.96 & 19.83 \\
\hline 9 & 2 & 5 & 10 & 6.40 & 0.183 & 1.071 & 12.31 & 1.64 & 3.45 & 4.59 & 9.91 & 20.54 \\
\hline 5 & 3 & 5 & 11 & 6.33 & 0.206 & 1.074 & 17.11 & 1.57 & 3.36 & 4.40 & 10.94 & 21.29 \\
\hline 2 & 4 & 7 & 9 & 6.47 & 0.169 & 1.066 & 8.20 & 1.68 & 3.65 & 4.67 & 8.88 & 19.76 \\
\hline 11 & 5 & 3 & 10 & 6.41 & 0.181 & 1.072 & 12.46 & 1.65 & 3.43 & 4.62 & 9.97 & 20.63 \\
\hline 12 & 6 & 5 & 10 & 6.40 & 0.182 & 1.070 & 12.40 & 1.63 & 3.44 & 4.57 & 9.94 & 20.53 \\
\hline 1 & 7 & 3 & 9 & 6.55 & 0.165 & 1.068 & 8.24 & 1.70 & 3.61 & 4.71 & 8.98 & 19.9 \\
\hline 6 & 8 & 5 & 10 & 6.43 & 0.183 & 1.071 & 12.43 & 1.64 & 3.45 & 4.59 & 9.96 & 20.58 \\
\hline 3 & 9 & 5 & 10 & 6.42 & 0.184 & 1.071 & 12.37 & 1.63 & 3.47 & 4.59 & 9.95 & 20.58 \\
\hline 4 & 10 & 5 & 10 & 6.41 & 0.182 & 1.070 & 12.41 & 1.62 & 3.46 & 4.58 & 9.93 & 20.54 \\
\hline 13 & 11 & 7 & 11 & 6.27 & 0.207 & 1.073 & 16.49 & 1.56 & 3.37 & 4.38 & 10.9 & 21.26 \\
\hline 7 & 12 & 3 & 11 & 6.34 & 0.202 & 1.075 & 17.14 & 1.57 & 3.34 & 4.41 & 10.96 & 21.27 \\
\hline 10 & 13 & 7 & 10 & 6.38 & 0.186 & 1.069 & 12.35 & 1.61 & 3.49 & 4.56 & 9.9 & 20.48 \\
\hline
\end{tabular}


Table.6 Coefficients of quadratic polynomial model for coded physico-chemical attributes

\begin{tabular}{|c|c|c|c|c|c|c|c|c|c|}
\hline Factor & pH & $\begin{array}{l}\text { Acidity } \\
\text { (\%LA) }\end{array}$ & Specific gravity & $\begin{array}{c}\text { Viscosity } \\
\text { (cP) }\end{array}$ & $\begin{array}{l}\text { Fat } \\
(\%)\end{array}$ & $\begin{array}{c}\text { Protein } \\
(\%)\end{array}$ & $\begin{array}{c}\text { Lactose } \\
(\%)\end{array}$ & $\begin{array}{c}\text { Sucrose } \\
(\%)\end{array}$ & $\begin{array}{c}\text { Total } \\
\text { Solid }(\%)\end{array}$ \\
\hline Intercept & 6.41 & 0.18 & 1.07 & 12.41 & 1.63 & 3.45 & 4.58 & 10.08 & 20.44 \\
\hline PBLE (A) & $-0.030 *$ & 2.333E-003* & $-1.167 \mathrm{E}-003 *$ & $-0.13^{*}$ & $-0.012 *$ & $0.022 *$ & $-0.022 *$ & -0.053 & -0.065 \\
\hline $\mathbf{A B}$ & $2.500 \mathrm{E}-003$ & $2.500 \mathrm{E}-004$ & 0.000 & $-0.15^{*}$ & 2500E-003 & $-2.500 \mathrm{E}-003$ & $2.500 \mathrm{E}-003$ & $5.000 \mathrm{E}-003$ & 0.028 \\
\hline $\mathbf{A}^{2}$ & -0.015 & $-2.414 \mathrm{E}-004$ & $-5.172 \mathrm{E}-005$ & -0.058 & $-2.241 \mathrm{E}-003$ & 4.310E-003 & $4.310 \mathrm{E}-003$ & -5.54 & -0.53 \\
\hline $\mathbf{B}^{2}$ & 0.010 & $3.259-003 *$ & $-5.172 \mathrm{E}-005$ & $0.20 *$ & $-2.241 \mathrm{E}-003$ & $0.034^{*}$ & $-0.046^{*}$ & 0.062 & 0.052 \\
\hline F-value & $56.91 *$ & $549.48 *$ & $74.25^{*}$ & $2079.83^{*}$ & $66.79 *$ & $200.78 *$ & $309.65^{*}$ & $6.02 *$ & $3.36 *$ \\
\hline Mean & 6.41 & 0.18 & 1.07 & 12.47 & 1.63 & 3.47 & 4.57 & 10.60 & 21.22 \\
\hline SD & 0.015 & 8.936E-004 & $4.691 \mathrm{E}-004$ & 0.10 & $8.425 \mathrm{E}-003$ & 0.011 & $9.349 \mathrm{E}-003$ & 0.40 & 0.40 \\
\hline Adeq Precision & 25.16 & 69.73 & 29.28 & 126.68 & 25.62 & 42.82 & 52.48 & 8.14 & 6.31 \\
\hline
\end{tabular}

Table.7 Predicted and actual sensory score of suggested formulation by design expert 7.0.0 package

\begin{tabular}{|c|c|c|c|c|c|c|c|}
\hline \multirow{2}{*}{$\begin{array}{l}\text { Sr. } \\
\text { no }\end{array}$} & \multirow{2}{*}{$\begin{array}{r}\text { Ingredients } \\
(\%)\end{array}$} & \multirow[t]{2}{*}{ Score } & \multicolumn{5}{|c|}{ Sensory parameters } \\
\hline & & & $\begin{array}{c}\text { Colour \& } \\
\text { appearance }\end{array}$ & Flavour & Consistency & Sweetness & Overall acceptability \\
\hline 1 & PBLE 5.15 & Predicted & 8.40 & 8.42 & 7.49 & 8.34 & 8.17 \\
\hline 2 & $\begin{array}{l}\text { Sugar } \\
10.30\end{array}$ & Actual & $\begin{array}{c}8.49 \\
\pm 0.05\end{array}$ & $\begin{array}{c}8.50 \\
\pm 0.06\end{array}$ & $\begin{array}{r}7.40 \\
\pm 0.04 \\
\end{array}$ & $\begin{array}{c}8.30 \\
\pm 0.08\end{array}$ & $\begin{array}{r}8.15 \\
\pm 0.01 \\
\end{array}$ \\
\hline \multicolumn{3}{|c|}{ T test } & $\begin{array}{c}0.09 \\
\pm 0.05\end{array}$ & $\begin{array}{c}0.08 \\
\pm 0.06\end{array}$ & $\begin{array}{c}0.09 \\
\pm 0.04\end{array}$ & $\begin{array}{c}0.04 \\
\pm 0.08\end{array}$ & $\begin{array}{c}0.02 \\
\pm 0.01\end{array}$ \\
\hline
\end{tabular}

Table.8 Distribution of consumers based on acceptance of Piper betel leaves flavoured milk

\begin{tabular}{|l|c|c|c|}
\hline Preference & Score & No. of respondent & Percentage \\
\hline Fair & 1 & 15 & $\mathbf{7 . 5}$ \\
\hline Good & 2 & 35 & $\mathbf{1 7 . 5}$ \\
\hline Very good & 3 & 47 & $\mathbf{2 3 . 5}$ \\
\hline Excellent & $\mathbf{4}$ & $\mathbf{1 1 3}$ & $\mathbf{5 6 . 5}$ \\
\hline
\end{tabular}


Fig.1 Flow diagram for manufacture of Piper betel leaves flavoured milk

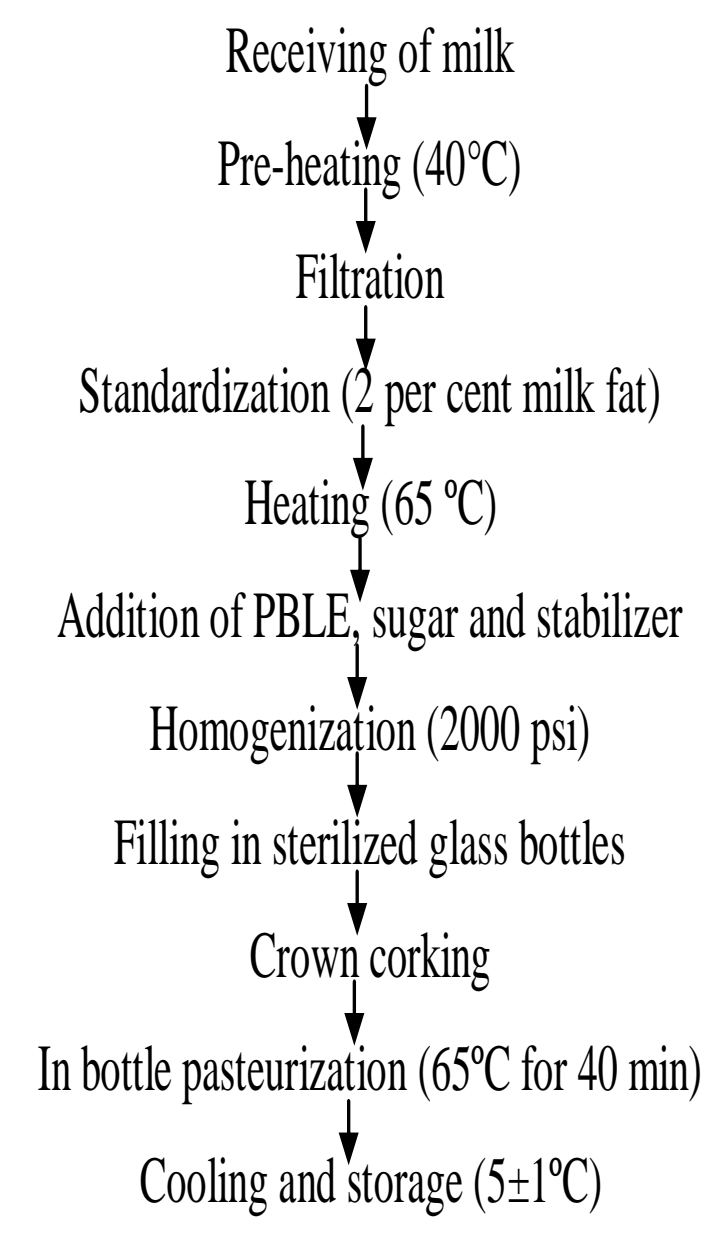




\section{Int.J.Curr.Microbiol.App.Sci (2019) 8(1): 713-724}

Design-Exper® Softwar

$\prod_{7.5}^{8.6}$

$\mathrm{X} 1=\mathrm{A}$
$\mathrm{X} 2 \mathrm{PBLE}(\%)$

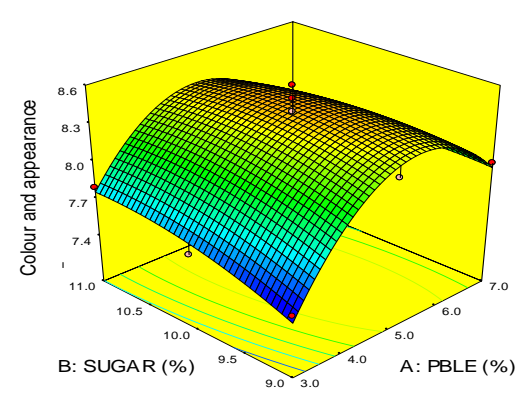

Fig.2 Effect of level of PBLE and sugar on color and appearance score of flavored milk

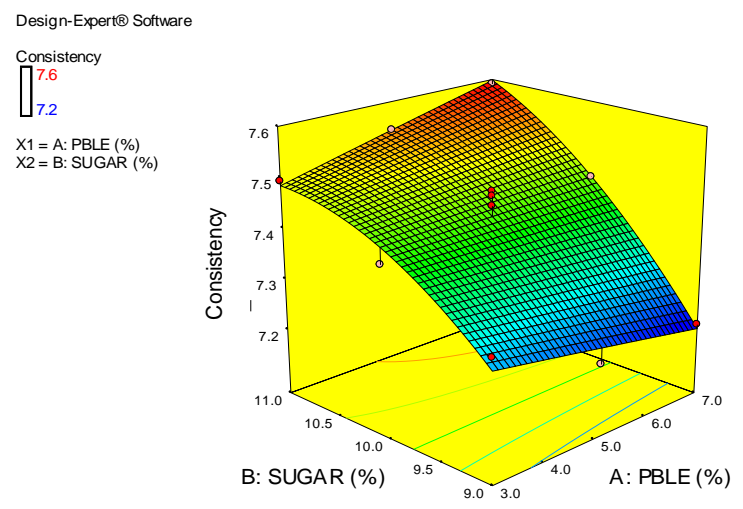

Fig.4 Effect of PBLE and sugar on consistency score

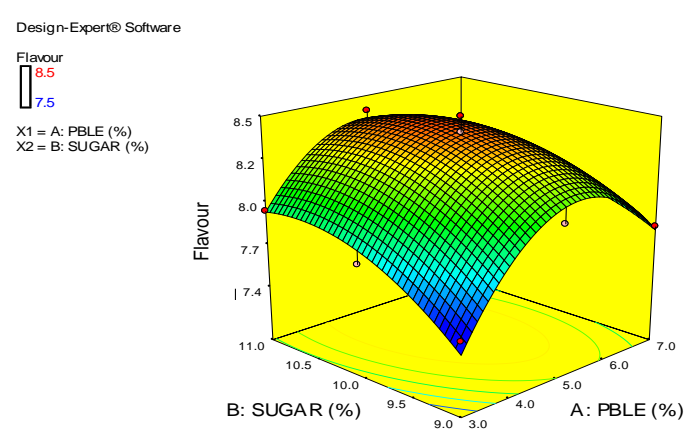

Fig.3 Effect of level of PBLE and sugar on flavour score of flavored milk

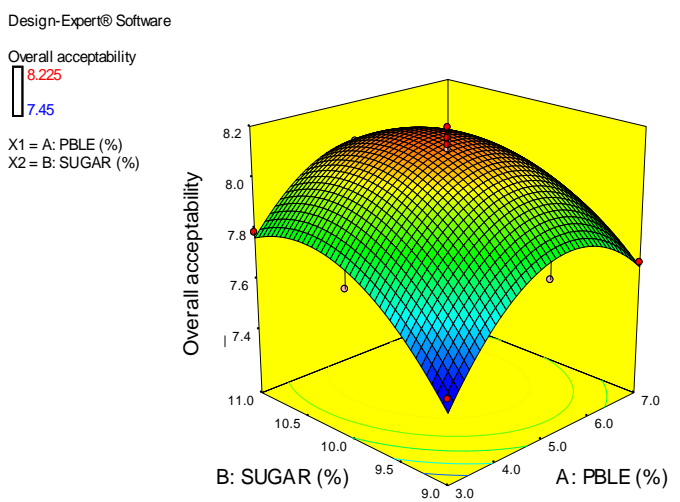

Fig.5 Effect of level of PBLE and sugar on overall acceptability score of flavored milk 


\section{Optimization of independent variables}

The optimization of the variable levels was achieved by desirable maximization of the sensory response along the fitted polynomial model by numerical optimization procedure of design expert software. The best solution exerted through the software and their predicted score is presented in Table 5.The optimized levels of PBLE and sugar were 5.15 and 10.30 per cent, respectively. The validation of the prediction was done by actual observations recorded for sensory score of flavored milk prepared by addition of PBLE and sugar at 5.15 and 10.30 per cent, respectively. The predicted and actual response values (obtained after making the product using the optimum level of ingredients) were almost similar. Hence, $5.15 \%$ PBLE and $10.30 \%$ sugar levelwas recommended. Optimized flavoured milk had $8.49,8.50,7.408 .30$ and 8.17 score for colour $\&$ appearance, flavour, consistency, sweetness and overall acceptability, respectively(Table 7).

\section{Consumer acceptance of piper betel flavored milk}

It was found that 56.5 per cent of the consumers reported excellent quality of Piper betel flavored milk and 23.5 per cent reported very good remark about quality of Piper betel flavored milk.(Table 8) Ritu et al., (2007) concluded that flavoured sweetened whey drink could be prepared by 4, 5 and 6 per cent mango pulp with highest consumer acceptability as compared to that of control

In conclusion use of Piper betel leaf extract of Calcutta variety in the preparation of flavored milk was significantly superior over the other two varieties under study. The most sensorial acceptable quality of Piper betel flavored milk can be prepared by using 5.15 per cent Piper betel leaves extract and 10.30 per cent sugar. The optimized formulated $(5.15 \%$ PBLE and $10.30 \%$ sugar) product had 6.40 $\mathrm{pH}, \quad 1.071$ specific gravity, $18.50 \quad(\mathrm{cP})$ viscosity and contained $01.64,3.50,4.55$, $10.15,0.95$ and 20.79 per cent fat, protein, lactose, sucrose, ash, and total solid, respectively.

\section{References}

A.O.A.C. 19950fficial Method of analysis 16th Edn.Association of Official Analytical Chemists. Washigton D. C. USA.

Bisig, W. Liquid milk products: Flavoured milks. Encyclopedia of Dairy Sci. II edn. Academic Press, Elsevier publication, New York, 201, pp: 301306

Manna, S. and Chakraborti, S., 2010. Values And Ethics In Business And Profession. PHI Learning Pvt. Ltd.

Food Safety and Standards Regulation Food safety and standards (Food products standards and food additives) regulations. 2011. www.fssai.gov.in.

Guha, P., 2006. Betel leaf: the neglected green gold of India. Journal of Human Ecology, 19(2), pp.87-93.

Henika, R.G., 1972. Simple and effective system for use with response surface methodology. Cereal Science Today, 17(10), p.309.

Hue, Y.H., 1993. Dairy science and technology hand book. I principle and properties. VCH publishers. Inc. New York, USA, Pp: 168-169.

Jothylingam, S. and Pugazhenthi, T.R., 2010. Development of dietetic herbal flavoured milk and analysis for it's physico chemical properties. International J. of Food, Agriculture and Veterinary Sci., 3 (1) pp. 54- 57.

Kumar, N., 1999. Betelvine (piper be tle 1.) Cultivation: a unique case of plant establishnient under anthropogenically 
regulated microclimatic conditions.

Mann, B., Rajesh, K. and Sharma, R., 2012. Determination of density and specific gravity. In Laboratory manual of physical chemistry of milk and milk products. NDRI, ICAR Publication, pp: 5-11.

Natisri, S., Mahattanatawee, K. and Thaiudom, S., 2014. Improving the flavor of soy ice cream by adding lemongrass or pandan leaf extracts. CMUJ NS Food and applied bioscience, 13(1): pp 459-481.

Oliveira, D., Antunez, L., Gimenez, A., John, C., Deliza, R. and Ares, G., 2015. Sugar reduction in probiotic chocolateflavored milk: Impact on dynamic sensory profile and liking. Food Research International, 75: pp 148-156.

Palthur, S., Anuradha, C.M. and Devanna, N., 2014. Development and evaluation of ginger flavored herbal milk. Res J Agric Env Sci, 1, pp. 54-59.

Poul, S.P., Sontakke, A.T., Munde, S.S. and Adangale, A.B., 2009. Composition and economics of custard apple milk shake. Asian Journal of Animal Science, 4(2), pp.139-142.
Rai, M.P., Thilakchand, K.R., Palatty, P.L., Rao, P., Rao, S., Bhat, H.P. and Baliga, M.S., 2011. Piper betel Linn (betel vine), the maligned Southeast Asian medicinal plant possesses cancer preventive effects: Time to reconsider the wronged opinion. Asian Pac J Cancer Prev, 12(9), pp.2149-56.

Ramamurthi, K. and Usha Rani, O., 2012. Betel leaves: Nature's green medicine. Facts for you, pp 8-10.

Ritu, P.D., Divya, and Ramakant, D., 2007. Effect of different treatments on the physico chemical and nutritional characteristics of whey-guava beverage. Indian Research J. of Extension Education, 7 (1): pp 27-29.

Sudha, S., Padmaja, A., Sutaria, H., Sailaja, P., Arvindakshan, P. and Rao, J., 2015. Utilization of lemongrass leaves extract in the preparation of flavoured milk, of 6th International conference on emerging technologies in food and nutrition for health management, NDRI, Bangalore, Technology In Food Processing, Pp: 18-19.

\section{How to cite this article:}

Vaibhav S. Kamble, Dnyaneshwar D. Patange, Dinakar K. Kamble, Karishma S. Kamble and Sharad J. Patil. 2019. Process Optimization for Flavoured Milk Added with Piper betel Leaves. Int.J.Curr.Microbiol.App.Sci. 8(01): 713-724. doi: https://doi.org/10.20546/ijcmas.2019.801.079 